\section{Sergio Bertini Curri}

\section{Enrico Oliva}

Department of Physiology and Pathophysiology, Faculty of Medicine, University of Ostrava, Czech Republic

\section{To my master Sergio Bertini Curri}

Nos esse quasi nanos gigantium humeris insidentes, ut possimus plura eis et remotiora videre, non utique proprii visus acumine, aut eminentia corporis, sed quia in altum sebvehimur et extollimur magnitudine gigantea.

One morning there was a beautiful sun and I was very excited and also very young. I had recently graduated, and I was in charge of presenting a paper at an important microcirculation congress at the Academy of Healthcare Art History in Rome. On that occasion, I presented the results of a work that came out of an intuition and that put me in a very alternative, non-academic vision. In fact, the discussion was characterized by criticism, and I was in real difficulty in front of an audience with many experts. I remember that the president of that session was Professor Raffaele Del Guercio. I was presenting my point of view when from the back of the room rose a voice with a strong character, a bit hoarse and sharp, which brought a respectful silence. I felt like giving in, instead it was a sword that rose to my aid. That man, tall and burly, clarifies to everyone, including me, the rationale of that work and concludes: good, this young man.

I asked who my savior was and I find out it was Professor Sergio Bertini Curri (Figure 1). Obviously I went to meet him and thank him, he welcomed me with severe sympathy and ended the chat with: if you want you can collaborate with me, let me see the things you do.

Yes, I had found my Socrates. Later I discovered that he was like that: available to everyone, curious, and loved young people. He was surrounded by young people, and he gave everyone help and a chance. Many of the best researchers in I.V. lymphology and microcirculation owe to him much of what they know and what they have done, presented and written. Sergio Bertini Curri was a generous man. Generous in all aspects of life, it should be remembered: even in drinking, eating and smoking. He embodied the Genius and Unregulation. He absorbed everything, he was crazy about knowing, investigating, and discovering.

I finally became his pupil, as he liked to call me, we traveled together everywhere, and everywhere I learned the culture, rules and ways of life of the place, without underestimating the typical wines and drinks and refined traditional dishes: being with him meant living and learning again and again. He was a polyglot, he spoke several languages perfectly, he loved to know everything: for him studying was like breathing. His expertise ranged from molecular biology, to marine biology, to archaeology: he had dedicated in-depth studies to bacterial aggression to monuments and frescoes. This allowed him to defend the marbles of the Parthenon of Athens and the Erechtheum. He dedicated himself to the study of the Etruscans and did a lot field research. $\mathrm{He}$ loved philosophy, poetry and literature. I remember that, at a dinner I had organized for one of my conferences, among the guests had been invited Alberto Moravia: they developed an instant connection and a great chatter between the masters began.

He liked fairy tales, and he wrote one as a preface to one of his books: Localized adiposity and panniculopathy edematous sclerotic fibro. Everything that fell under his attention became a matter of research. His best quality? The Intuition. Yes: he was a visionary, in his mind the future reality was preformed, he already saw the results of an investigation not yet started. As usual, however, everyone has the merits of his own faults and the faults of his own merits: he was a dreamer, disconnected from the earth, he would forget the practical things of everyday life, and if his attentive and loving wife, Mirella, hadn't been beside him, thinking about making the ends meet, what a mess! She was able to organize an entire scientific article complete with a bibliography, and she did it so many times with me and his other pupils

There have been so many who have drawn on his knowledge and his teaching, and many of them are now leading figures in the world of angiology and the microcirculation. His intellectual freedom, his vision of boundless research led him to collaborate with many great minds. I can only remember a few of those, after so many years: Terence Ryan, Friedrich Tischendorf, Jean Francois Merlen, Carlo Alberto Bartoletti, Claudio Allegra.

Sergio Bertini Curri was born in Fiume, a borderland now lost, he became a professor of anatomy, pathology and histochemistry with a passion for molecular biology and biochemistry. Least but not the last, he had a predilection for dermo-cosmetological problems on a micro vascular basis. Citing his immense scientific production, more than 500 publications and dozens of scientific texts, fails to convey the real
Correspondence: Enrico Oliva, Department of Physiology and Pathophysiology, Faculty of Medicine, University of Ostrava, Czech Republic.

E-mail: enrico.ol@libero.it

Key words: Italian Phlebolymphology; history; Masters of the past; phlebology; lymphology.

Conflict of interests: the author declares no potential conflict of interests.

This paper is part of the monographic issue: 'Did the Masters of the past know the future? History and update of Italian Phlebolymphology' - Guest editor: Alberto Macciò (Phlebology - Part I edited by G. Agus; Phlebology - Part II edited by P. Bonadeo; Lymphology edited by F. Boccardo).

Received for publication: 30 June 2020. Revision received: 10 July 2020

Accepted for publication: 15 July 2020.

This work is licensed under a Creative Commons Attribution 4.0 License (by-nc 4.0).

CCopyright: the Author(s), 2020

Licensee PAGEPress, Italy

Veins and Lymphatics 2020; 9:9251

doi:10.4081/vl.2020.9251

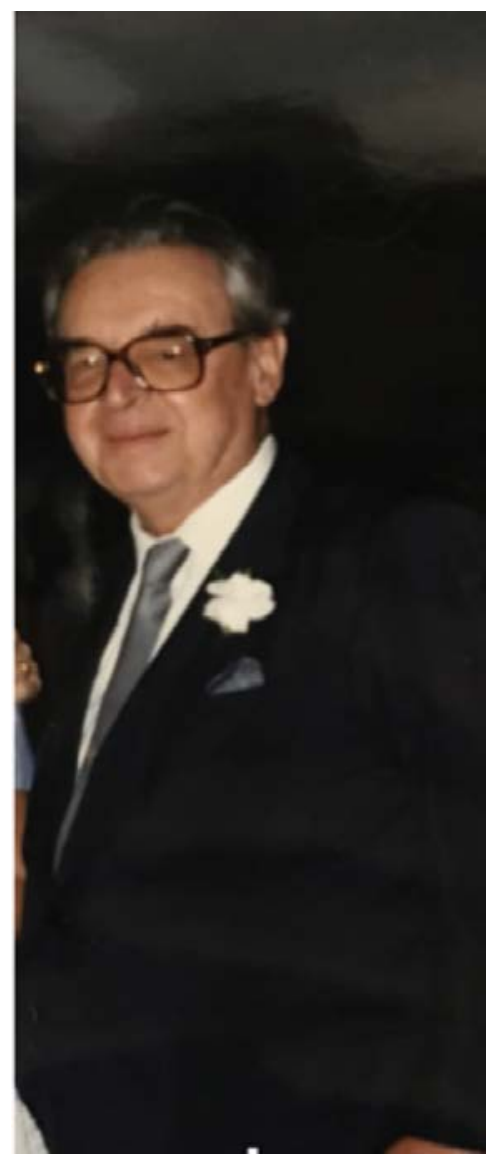

Figure 1. Professor Sergio Bertini Curri. 
value of his work and how it has affected the formation and growth of many researchers, let alone how much it has contributed to the development of research. His biomolecular training has led him to deal with natural pharmacology in unsuspicious times. He had always been a bit of a heretic, as when he founded with Prof. Raffaele Del Guercio, Prof. Claudio Allegra and others, the GISLD, the Italian study group on the Laser-Doppler. He wanted me to be in the board and act as secretary of the company, to walk together in his umpteenth adventure. We seemed to be alchemists fascinated by mysterious waves, busy decoding them and understanding their secret language. He was a wise man, steeped in Central European culture, shaped by classical philosophy and Greek mythology. He studied with great interest symbols, and he always said: Symbols speak only to those who know them, the same concept expressed by Thomas Mann: man sees what he knows.
Along this path, he associated the clinical picture of mammary panniculopathy from stasis with edematous-fibrosclerotic panniculopathy, producing the acronyms PEM and PEFS, now universally accepted. We remember that in those years fibrocystic mastopathy was still a demonized pathology. He participated and stimulated the foundation of the MFCGroup (Group on fibrocystic breast mastopathy) to spread the new discoveries I lived with my Master also this experience. A thousand are the memories that bind me to him, who by choice of both, has become my acquired father, as much to leave me as heir to his position at the University of Siena, at the school of specialization of Prof. Serio Mancini. Many are the funny and amusing moments, like when he went in search of the worst breweries in London, or how when sunbathing on the ground at Torre dell'Orso, he was reading a magazine American aerospace, screamed Eureka!. Videocapillaroscopy optical probe was born, months later we published the first thesis in the world on the study of skin microcirculation with VCSO.

So many memories are very affectionate, as one evening when I kept repeating Professor, Professor. He looked into my eyes, and took my hand in his and said to me: Enrico you're boring me, my name is Sergio. I was surprised and could hardly contain my emotion. There is no greater gratification for a pupil than to be welcomed like this by the Master.

But he was stubborn. He didn't want to treat his aches and pains, he just kept smoking his cigarettes without a filter, eating and drinking without worrying about anything: you couldn't get him to change his style.

Thank you, Sergio, for what you have given us with your teaching. I prefer to quote you now: Stop the games. Do you remember? When we started an adventure you would always say to me, Let's play now. 